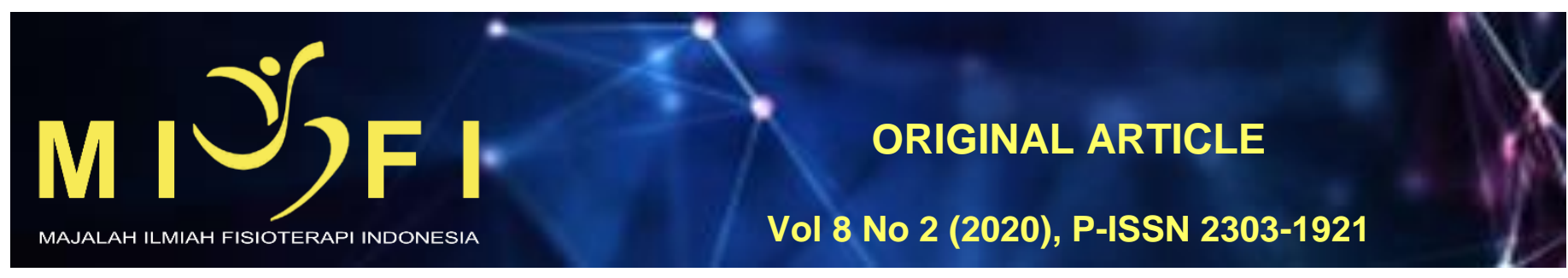

\title{
HUBUNGAN INDEKS MASSA TUBUH (IMT) TERHADAP DISFUNGSI EREKSI PADA PEGAWAI KANTOR DI KOTA DENPASAR
}

\author{
Ida Bagus Komang Ari Krisnayana ${ }^{1}$, Ni Wayan Tianing ${ }^{2}$, Ari Wibawa ${ }^{3}$, M. Widnyana ${ }^{4}$ \\ ${ }^{1}$ Program Studi Sarjana Fisioterapi dan Profesi Fisioterapi, Fakultas Kedokteran Universitas Udayana \\ ${ }^{2}$ Departemen Biokimia Fakultas Kedokteran Universitas Udayana \\ ${ }^{3,4}$ Departemen Fisioterapi Fakultas Kedokteran Universitas Udayana \\ gusmangari96@gmail.com
}

\begin{abstract}
ABSTRAK
Indeks Massa Tubuh (IMT) adalah rasio standar berat terhadap tinggi badan sehingga dapat melihat apakah seseorang memiliki massa tubuh yang ideal, terlalu kurus, kelebihan berat badan, atau obesitas. Pegawai kantor merupakan pekerjaan yang memiliki prevalensi berat badan berlebih dan obesitas tertinggi dibandingkan profesi lainnya. Kelebihan berat badan dapat menimbulkan berbagai masalah kesehatan, salah satunya adalah gangguan aktivitas seksual seperti disfungsi ereksi. Tujuan dari penelitian ini adalah untuk membuktikan bahwa Indeks Massa Tubuh (IMT) berhubungan dengan disfungsi ereksi pada pegawai kantor di Kota Denpasar. Penelitian ini menggunakan rancangan penelitian cross sectional analitik yang dilakukan pada bulan April 2019. Jumlah sampel dalam penelitian ini adalah 58 orang laki-laki yang sudah menikah dengan usia 30-40 tahun. Teknik pengambilan sampel dilakukan dengan teknik purposive sampling. Variabel independen dalam penelitian ini adalah Indeks Massa Tubuh yang diukur menggunakan timbangan dan microtoise stature meter, sedangkan variabel dependen dalam penelitian ini adalah disfungsi ereksi yang diketahui dengan menggunakan kuisioner IIEF-5. Teknik analisis data yang dilakukan yaitu uji bivariat dengan Spearman's Rho untuk mengetahui ada atau tidaknya hubungan, kekuatan hubungan dan arah hubungan. Hasil penelitian menunjukkan nilai $p=0,001 \quad(p<0,05)$ dengan nilai $r=0,520$. Berdasarkan hasil penelitian tersebut maka dapat disimpulkan bahwa hubungan Indeks Massa Tubuh dengan disfungsi ereksi pada pegawai kantor di Kota Denpasar memiliki hubungan yang kuat, signifikan dan searah.
\end{abstract}

Kata Kunci : indeks massa tubuh, disfungsi ereksi, pegawai kantor

\section{CORRELATION OF BODY MASS INDEX (BMI) WITH ERECTILE DYSFUNCTION IN OFFICE EMPLOYEES AT DENPASAR CITY}

\section{ABSTRACT}

The Body Mass Index (BMI) is the standard weight to height ratio so you can see if someone has an ideal body mass, is too thin, is overweight, or obese. Office employees are jobs that have the highest prevalence of overweight and obesity compared to other professions. Being overweight can cause various health problems, one of which is a disruption of sexual activity such as erectile dysfunction. The purpose of this study was to prove that the Body Mass Index (BMI) was associated with erectile dysfunction in office employees in Denpasar City. This study used a crosssectional analytical study design conducted in April 2019. The number of samples in this study was 58 married men aged 30-40 years. The sampling technique is done by purposive sampling technique. The independent variable in this study is the Body Mass Index measured using scales and microtoise stature meters, while the dependent variable in this study is erectile dysfunction which is known by using the IIEF-5 questionnaire. The data analysis technique is done by the bivariate test with Spearman's Rho to find out whether there is a relationship, the strength of the relationship and the direction of the relationship. The results showed the value of $p=0.001(p<0.05)$ with a value of $r=0.520$. Based on the results of these studies, it can be concluded that the relationship of the Body Mass Index with erectile dysfunction in office employees in the City of Denpasar has a strong, significant and direct relationship.

Keywords: body mass index, erectile dysfunction, office employees 


\section{PENDAHULUAN}

Perkembangan jaman dan peningkatan status sosial ekonomi, menyebabkan pergeseran gaya hidup yang berdampak positif dan negatif seperti penurunan tingkat aktivitas fisik dan meningkatnya konsumsi makanan cepat saji. Tidak seimbangnya antara asupan makanan dengan aktivitas fisik yang kurang sehingga akan meningkatkan indeks massa tubuh (IMT). ${ }^{1}$ Beberapa faktor yang dapat mempengaruhi indeks massa tubuh adalah usia, jenis kelamin, genetik, pola makan dan aktivitas fisik. ${ }^{2}$

Berdasarkan Riset Kesehatan Dasar Tahun 2013, prevalensi penduduk laki-laki dewasa obesitas pada tahun 2013 sebanyak 19,7\% meningkat dari tahun 2007 yaitu sebesar 13,9\% dan tahun 2010 sebesar 7,8\%. ${ }^{3}$ Riset Kesehatan Dasar Provinsi Bali Tahun 2013, melaporkan pegawai kantor merupakan pekerjaan yang memiliki prevalensi berat badan berlebih dan obesitas tertinggi dibandingkan profesi lainnya. ${ }^{4}$ Hal ini dikarenakan pegawai kantor memiliki gaya hidup dalam bekerja yang kurang bergerak dan pola konsumsi makanan berlemak yang tinggi. 4,5

Kelebihan berat badan dapat mengganggu aktivitas seksual, sebuah penelitian dilakukan oleh Husain yang membahas tentang pengaruh kelebihan berat badan atau overweight terhadap terjadinya disfungsi seksual pada pria, di dapatkan data bahwa dari 30 pria terdapat 9 orang dengan disfungsi ereksi ringan. ${ }^{6}$ Semakin tinggi nilai IMT maka semakin tinggi risiko terjadinya disfungsi seksual. Sejalan dengan penelitian yang dilakukan oleh Hiola diperoleh hasil bahwa dari 60 pria obesitas terdapat 30 orang dengan disfungsi ereksi. ${ }^{7}$

Disfungsi ereksi atau erectile dysfunction adalah ketidakmampuan seorang pria dalam mencapai ataupun mempertahankan ereksi yang cukup untuk melakukan aktivitas seksual yang memuaskan. ${ }^{8}$ Insidensi disfungsi ereksi paling banyak pada lelaki lebih muda dari 40 tahun, tetapi meningkat sesuai usia sehingga disfungsi ereksi diasumsikan sebagai gejala proses penuaan pada laki-laki. ${ }^{9}$ Secara umum disfungsi ereksi disebabkan oleh beberapa faktor risiko yaitu : (1) Usia, ketika seseorang semakin tua, sel otot polos cavernosus semakin berkurang sehingga mengakibatkan ketidakmampuan jaringan rongga lakuna untuk mempertahankan dan mencegah aliran darah keluar dari rongga lakuna. ${ }^{10}$ (2) Diabetes Mellitus (DM), gula darah dalam tubuh yang tidak terkontrol dapat merusak sel-sel sarah, pembuluh darah dan menyebabkan disfungsi endotel. ${ }^{11}$ (3) Hipertensi, pada pasien hipertensi fungsi endotelium tidak mampu menghasilkan dilatasi penis, sehingga mengakibatkan penurunan persistensi ereksi. ${ }^{12}$ (4) Obesitas, pada pria obesitas terjadi kerusakan pada endotelium dan perubahan hormon testosteron menjadi estrogen. ${ }^{7}(5)$ Kurang aktivitas fisik, aktivitas fisik dikaitkan menjadi faktor protektif terhadap masalah ereksi, hal ini karena aktivitas fisik berpengaruh terhadap terpeliharanya kapasitas organ-organ faal tubuh.13,14 (6) Merokok, nikotin dapat menyempitkan pembuluh darah yang menuju penis, mempengaruhi fungsi endotel dan otot polos cavernosus. ${ }^{15,16}$ (7) Obat-obatan, Obat-obatan seperti antridepresan, neuroleptik, obat penenang, beta blocker, dan diuretik dapat menyebabkan efek samping seksual seperti disfungsi ereksi. ${ }^{17}$

Disfungsi ereksi dapat mempengaruhi kesehatan fisik maupun psikososial dan memiliki dampak yang signifikan terhadap kualitas hidup (quality of life) pasien dan pasangannya hingga menyebabkan kematian, hal ini dikarenakan disfungsi ereksi tidak hanya dianggap sebagai masalah kualitas hidup, tetapi juga sebagai tanda peringatan potensial penyakit kardiovaskular. ${ }^{18}$ Penelitian yang dilakukan oleh Araujo berjudul Erectile Dysfunction and Mortality didapatkan hasil pria dengan disfungsi ereksi memiliki risiko $26 \%$ lebih tinggi menyebabkan kematian dibandingkan dengan pria tanpa disfungsi ereksi. ${ }^{19}$

Berdasarkan latar belakang masalah diatas, penulis tertarik untuk melakukan penelitian tentang hubungan indeks massa tubuh (IMT) terhadap disfungsi ereksi pada pegawai kantor Di Kota Denpasar.

\section{METODE PENELITIAN}

Penelitian ini merupakan penelitian observasional yang menggunakan rancangan penelitian analitik dengan metode cross sectional yang bertujuan untuk mengetahui hubungan indeks massa tubuh (IMT) terhadap disfungsi ereksi pada pegawai kantor di Kota Denpasar. Penelitian ini dilakukan pada bulan April 2019 di Gedung Sewaka Dharma yang beralamat di Jalan Majapahit No. 1 Lumintang, Denpasar. Sampel dalam penelitian ini berjumlah 58 orang pegawai kantor dengan teknik pengambilan sampel purposive sampling yaitu pemilihan berdasarkan kriteria inklusi dan eksklusi yang ditentukan sesuai dengan tujuan penelitian dengan cara wawancara dan pengukuran secara lengkap dan sistematis. Kriteria inklusi penelitian ini yaitu bersedia menjadi sampel penelitian dengan mengisi dan menandatangani informed consent, berusia 30-40 tahun, laki-laki yang sudah menikah, lulus tes L-MMPI (Lie-Score Minnesota Multiphase Personality Inventory). Sedangkan yang termasuk dalam kriteria eksluksi yaitu memiliki riwayat Diabetes Melitus (DM), memiliki riwayat hipertensi, merokok dan mengkonsumsi obat-obatan (antidepresan, neuroleptik, obat penenang, beta bloker dan diuretik). Variabel independen dalam penelitian ini adalah Indeks Massa Tubuh (IMT), variabel dependen yaitu disfungsi ereksi dan variabel kontrol pada peneltian ini adalah usia dan aktivitas fisik (aktivitas fisik sedang). Usia ditentukan berdasarkan data pada Kartu Tanda Penduduk (KTP) dan aktivitas fisik diukur menggunakan kuisioner International Physical Activity Quistionaire (IPAQ) versi Short-Form.

Prosedur penelitian yaitu peneliti melakukan proses perijinan pada institusi tempat penelitian. Selanjutnya peneliti membuat informed consent yang harus ditandatangani subjek, yang isinya bahwa subjek bersedia menjadi sampel penelitian ini sampai selesai. Peneliti memberikan edukasi kepada subjek yang diteliti mengenai manfaat, tujuan, bagaimana penelitian ini dilakukan, setelah itu peneliti mewawancarai dan melakukan pengukuran untuk menginklusi dan eksklusi sampel. Setelah memenuhi jumlah minimal sampel, peneliti mengukur indeks massa tubuh, berat badan diukur menggunakan timbangan dan tinggi badan diukur menggunakan microtoise stature meter, setelah itu diklasifikasikan menurut Kemenkes tahun 2013. Sesudah pengukuran tersebut dilanjutkan pengukuran disfungsi ereksi dengan menyebarkan kuisioner International Index of Erectile Dysfunction - 5 (IIEF-5). Data dari hasil keseluruhan pengukuran tersebut akan diolah secara statistik dengan SPSS versi 25. Analisis data yang digunakan berupa uji univariat untuk mengetahui gambaran masing-masing variabel dan uji bivariat dengan Spearman's Rho digunakan untuk mengetahui hubungan, kuat hubungan dan arah hubungan variabel independen terhadap variabel dependen. 
Tingkat signifikansi yang digunakan adalah $95 \%$ yang berarti $\alpha=0,05$. Nilai $p<\alpha$ menunjukkan bahwa terdapat hubungan antara indeks massa tubuh (IMT) terhadap disfungsi ereksi pada pegawai kantor di Kota Denpasar.

\section{HASIL}

Jumlah sampel yang telah memenuhi kriteria inklusi dan kriteria eksklusi sebanyak 58 orang. Karakteristik responden berdasarkan usia, Indeks Massa Tubuh (IMT) dan disfungsi ereksi adalah sebagai berikut.

Tabel 1. Distribusi Frekuensi Karakteristik Responden

\begin{tabular}{lll}
\hline Variabel & Frekuensi (n) & Persentase (\%) \\
\hline Usia & & \\
\hline $30-32$ & 17 & 29,3 \\
$33-34$ & 9 & 15,5 \\
$35-36$ & 8 & 13,8 \\
$37-38$ & 11 & 19 \\
$39-40$ & 13 & 22,4 \\
\hline Indeks Massa Tubuh (IMT) & & \\
\hline Underweight & 4 & 6,9 \\
Normal & 25 & 43,1 \\
Overweight & 12 & 20,7 \\
Obesitas & 17 & 29,3 \\
\hline Disfungsi Ereksi & & \\
\hline Positif (+) & 31 & 53,4 \\
Negatif (-) & 27 & 46,6 \\
\hline
\end{tabular}

Tabel 1 menunjukkan bahwa dari 58 responden pegawai kantor di Kota Denpasar, frekuensi responden tertinggi berada pada usia 30 - 32 tahun yaitu sebanyak 17 orang $(29,3 \%)$ dan terendah pada usia 35 - 36 tahun yaitu sebanyak 8 orang (13,8\%). Distribusi responden berdasarkan Indeks Massa Tubuh (IMT), frekuensi responden tertinggi dengan kategori normal sebanyak 25 orang $(43,1 \%)$, diikuti dengan frekuensi responden kategori obesitas sebanyak 17 orang $(29,3 \%)$, selanjutnya frekuensi responden kategori overweight sebanyak 12 orang $(20,7 \%)$ dan frekuensi responden terendah dengan kategori underweight sebanyak 4 orang. Berdasarkan disfungsi ereksi, didapatkan hasil responden dengan disfungsi ereksi positif $(+)$ sebanyak 31 orang $(53,4 \%)$ dan responden dengan disfungsi ereksi negatif $(-)$ sebanyak 27 orang $(46,6 \%)$.

Tabel 2. Korelasi Indeks Massa Tubuh (IMT) dengan Disfungsi Ereksi

\begin{tabular}{|c|c|c|c|c|c|}
\hline \multirow{2}{*}{ Indeks Massa Tubuh (IMT) } & \multicolumn{2}{|c|}{ Disfungsi Ereksi } & \multirow[t]{2}{*}{ Total } & \multirow[t]{2}{*}{$p$} & \multirow[t]{2}{*}{$r$} \\
\hline & Positif (+) & Negatif (-) & & & \\
\hline \multirow{2}{*}{ Underweight } & 0 & 4 & 4 & & \\
\hline & $0 \%$ & $-100 \%$ & $-100 \%$ & & \\
\hline \multirow{2}{*}{ Normal } & 9 & 16 & 25 & & \\
\hline & $-36 \%$ & $-64 \%$ & $-100 \%$ & $0 \cap 01$ & O 52 \\
\hline \multirow{2}{*}{ Overweight } & 7 & 5 & 12 & 0,001 & 0,52 \\
\hline & $-58,30 \%$ & $-41,70 \%$ & $-100 \%$ & & \\
\hline \multirow{2}{*}{ Obesitas } & 15 & 2 & 17 & & \\
\hline & $-88,20 \%$ & $-11,80 \%$ & $-100 \%$ & & \\
\hline Total & $\begin{array}{c}31 \\
-53,40 \%\end{array}$ & $\begin{array}{c}27 \\
-46,60 \%\end{array}$ & $\begin{array}{c}58 \\
-100 \%\end{array}$ & & \\
\hline
\end{tabular}

Berdasarkan tabel 2, dapat dilihat bahwa frekuensi Indeks Massa Tubuh (IMT) dengan disfungsi ereksi positif $(+)$ tertinggi pada kategori obesitas sebanyak 15 orang $(88,2 \%)$ dan terendah pada kategori underweight sebanyak 0 orang $(0 \%)$. Dan frekuensi Indeks Massa Tubuh (IMT) dengan disfungsi ereksi negatif (-) tertinggi pada kategori normal sebanyak 16 orang $(64 \%)$ dan terendah pada kategori obesitas sebanyak 2 orang $(11,8 \%)$.

Dari hasil output data di atas diketahui bahwa nilai $n$ atau jumlah data peneliti sebanyak 58 responden, kemudian nilai $p$ sebesar 0,001, karena nilai $p$ sebesar 0,001 lebih kecil dari 0,05 maka disimpulkan bahwa ada hubungan yang signifikan antara Indeks Massa Tubuh (IMT) dengan disfungsi ereksi pada pegawai kantor di Kota Denpasar. Dan pada data diatas dapat diketahui Correlation coefficient sebesar $(\mathrm{r}=0,520)$ yang artinya semakin tinggi Indeks Massa Tubuh (IMT) maka disfungsi ereksi akan meningkat. Dengan angka Correlation coefficient sebesar 0,520 dan angka signifikansi sebesar $\mathrm{p}=0,001$ maka nilai ini mempunyai makna bahwa hubungan Indeks Massa Tubuh dengan disfungsi ereksi pada pegawai kantor di Kota Denpasar memiliki hubungan yang kuat, signifikan dan searah.

\section{DISKUSI \\ Karakteristik Sampel}

Responden yang dipilih merupakan pegawai kantor laki-laki yang sudah menikah dengan usia 30-40 tahun karena dianggap pada usia tersebut belum mengalami penurunan kadar testosteron dan hilangnya sel otot polos cavernosus. ${ }^{10}$ Hasil penelitian berdasarkan Indeks Massa Tubuh (IMT) menunjukkan terdapat 29 orang (50\%) pegawai kantor memiliki massa tubuh diatas normal, hal ini disebabkan karena aktivitas fisik dan IMT memiliki hubungan yang kuat, obesitas lebih banyak pada laki-laki yang memiliki pekerjaan sedentarian dibandingkan dengan laki-laki yang memiliki pekerjaan aktif. ${ }^{20,21}$ Distribusi responden berdasarkan disfungsi ereksi, didapatkan hasil responden dengan 
disfungsi ereksi positif (+) sebanyak 31 orang (53,4\%) dan paling banyak adalah pada orang dengan Indeks Massa Tubuh (IMT) obesitas yaitu sebanyak 15 orang $(88,2 \%)$.

\section{Hubungan Indeks Massa Tubuh dengan Disfungsi Ereksi}

Berdasarkan pada tabel 2 dapat dilihat bahwa frekuensi responden pada kategori IMT underweight dengan disfungsi ereksi (+) sebanyak 0 orang (0\%) dan disfungsi ereksi (-) sebanyak 4 orang (100\%). Ini disebabkan karena underweight tidak termasuk dalam faktor risiko disfungsi ereksi. Pada kategori IMT normal dengan disfungsi ereksi $(+)$ sebanyak 9 orang (36\%) dan disfungsi ereksi (-) sebanyak 16 orang (64\%). Hal ini disebabkan karena pada IMT normal tidak terjadi aromatisasi dan fungsi dari endothelium untuk menghasilkan Nitrit Oksida (NO) tidak mengalami gangguan.

Pada kategori IMT overweight dengan disfungsi ereksi (+) sebanyak 7 orang (58,3\%) dan disfungsi ereksi (-) sebanyak 5 orang $(41,7 \%)$. Sejalan dengan penelitian yang dilakukan oleh Husain didapatkan hasil bahwa pria dengan IMT overweight memiliki risiko lebih tinggi untuk mengalami disfungsi ereksi. ${ }^{6}$ Pada kategori IMT obesitas dengan disfungsi ereksi (+) sebanyak 15 orang (88,2\%) dan disfungsi ereksi (-) sebanyak 2 orang (11,8\%). Hal ini sejalan dengan penelitian yang dilakukan oleh Hiola dengan judul pengaruh obesitas terhadap terjadinya disfungsi seksual pria, didapatkan 21 orang dengan disfungsi ereksi (+) dan 5 orang dengan disfungsi ereksi (-) dan diperoleh nilai $p=0,000$ pada komponen fungsi ereksi. ${ }^{7}$

Terdapat pula penelitian yang dilakukan oleh Diaz-Arjonilla berjudul obesity, low testosterone levels and erectile dysfunction, dimana pada penelitian ini fungsi ereksi dibagi menjadi dua bagian yaitu kekakuan ereksi dan kepuasan ereksi, didapatkan hasil masing-masing $p=0,023$ dan $p=0,010$ sehingga menunjukkan bahwa ada hubungan yang signifikan antara obesitas dan disfungsi ereksi. ${ }^{22}$

Indeks Massa Tubuh (IMT) adalah rasio standar berat terhadap tinggi badan yang diukur menggunakan rumus IMT, sehingga dapat melihat apakah seseorang memiliki massa tubuh yang ideal, terlalu kurus, kelebihan berat badan, atau obesitas. ${ }^{23}$ Semakin tinggi nilai IMT maka akan menyebabkan disfungsi endotel dan meningkatkan aromatisasi, yaitu perubahan hormon testosteron menjadi hormon estrogen sehingga hormon testosteron akan berkurang, dimana hormon testosteron ini berperan penting dalam proses ereksi, hal ini disebabkan karena hormon testosteron dapat memproduksi Nitrit Oksida (NO) yang berguna untuk melebarkan pembuluh darah salah satunya adalah pembuluh darah di penis. Apabila Nitrit Oksida (NO) tidak dihasilkan akan menyebabkan pembuluh darah pada penis sulit melebar yang mengakibatkan aliran darah ke organ erektil berkurang sehingga terjadilah disfungsi ereksi. ${ }^{11,24,25}$

Obesitas merupakan faktor risiko penting bagi banyak penyakit umum termasuk disfungsi ereksi. Pada kondisi IMT normal, tidak terjadi peningkatan jaringan adiposa dan pada pria obesitas, leptin akan meningkat sebanding dengan nilai IMT mereka Kadar leptin yang tinggi menginduksi disfungsi endotel, meningkatkan tekanan darah, dan menurunkan produksi testosteron. Diketahui bahwa Indeks Massa Tubuh (IMT) berbanding terbalik dengan kadar testosteron total yang artinya semakin tinggi nilai IMT maka kadar testosteron akan semakin rendah. Studi terbaru juga menunjukkan bahwa Indeks Massa Tubuh (IMT) juga berbanding terbalik dengan kadar testosteron bebas. Peningkatan aromatisasi yang terjadi menyebabkan peningkatan hormon estrogen, berkurangnya sintesis Nitrit Oksida (NO), rendahnya kadar hormon testosteron total, testosteron bebas dan SHBG (Sex Hormone Binding Globulin). Hormon estrogen akan menekan sekresi LH dan akhirnya menekan produksi hormon testosteron yang berperan penting dalam fungsi seksual pria. 22,26

\section{SIMPULAN}

Berdasarkan hasil dari analisis data yang telah dilakukan, dapat disimpulkan bahwa ada hubungan antara Indeks Massa Tubuh (IMT) dengan disfungsi ereksi pada pegawai kantor di Kota Denpasar. Keterbatasan pada penelitian ini hanya meniliti satu variabel independen yaitu Indeks Massa Tubuh, sehingga bagi peneliti selanjutnya yang ingin mengambil judul penelitian yang sama diharapkan dapat melakukan penelitian lebih lanjut, baik dengan menambahkan variabel independen yang lain seperti aktivitas fisik dan meneliti variabel perancu lainnya seperti merokok, hipertensi dan diabetes mellitus mengingat disfungsi ereksi ini merupakan penyakit multifaktorial.

\section{DAFTAR PUSTAKA}

1. Popkin B.M. Technology, transport, globalization and the nutrition transition food policy. Food Policy. 2006:31(6).

2. Sugiritama IW, Wiyawan IGNS, Arijana IGK, Ratnayanti IGA. Gambaran IMT (Indeks Massa Tubuh) Kategori Berat Badan Lebih dan Obesitas Pada Masyarakat Banjar Demulih, Kecamatan Susut, Kabupaten Bangli. Bagian Histologi Fakultas Kedokteran Universitas Udayana. 2015;2.

3. Kementrian Kesehatan RI. Riset Kesehatan Dasar (RISKESDAS) 2013. Jakarta Badan Penelitian dan Pengembangan Kesehatan Departemen Kesehatan Republik Indonesia. 2013;262.

4. Pranata S, Fauziah Y, Budisuari MA, Kusrini I. Riskesdas Provinsi Bali Tahun 2013. 2013;301. Available from : http://terbitan.litbang.depkes.go.id/penerbitan/index/.php/blp/catalog/book/112.

5. Moray FA, Rattu JAM, Josephus J. Faktor-Faktor Yang Berhubungan dengan aktivitas fisik pada pegawai Pt. Bank Negara Indonesia (BNI) Cabang Manado Tahun 2015. Jurnal Ilmiah Farmasi. 2016;5(1):290-296.

6. Husain A. Pengaruh Kelebihan Berat Badan / Overweight Terhadap Terjadinya Disfungsi Seksual Pria. Jurnal eBiomedik. 2015;3:782-785.

7. Hiola Z. Pengaruh Obesitas Terhadap Terjadinya Disfungsi Seksual Pria. Jurnal e-Biomedik. 2013;1(1):686-690.

8. Muneer A, Kalsi J, Narazeth I, Arya M. Erectile Dysfunction. BMJ. 2014;348:1-9.

9. Kharisma Y. Tinjauan Umum Penyakit Disfungsi Ereksi. Fakultas Kedokteran Universitas Islam Bandung.2017.

10. Ferrini MG, Gonzalez-Cadavid NF, Rajfer J. Aging Related Erectile Dysfunction-Potential Mechanism to Halt or Delay its Onset. Translational Andrology And Urology. 2017;6(1):20-27. 
11. Dodie NJ. Pengaruh Lamanya Diabetes Melitus Terhadap Terjadinya Disfungsi Ereksi. Jurnal E-Biomedik. 2013;1(3):1120-1125.

12. Javaroni V, Neves MF. Erectile Dysfunction and Hypertension: Impact on Cardiovascular Risk and Treatment. International Journal of Hypertension. 2012.

13. Gerbild H, Larsen CM, Graugaard C, Areskoug Josefsson K. Physical Activity to Improve Erectile Function: Systematic Review of Intervention Studies. Sexual Medicine.2018;6:75-89.

14. Mappaompo MA. Obesitas Dan Olahraga. Jurnal ILARA. 2010;1(2):10-16.

15. Rusdi S. Hubungan Antara Merokok Dengan Terjadinya Disfungsi Ereksi Pada Sopir Angkutan Umum di Terminal Karombasan Manado. Jurnal e-Biomedik. 2016;4(2).

16. Turalaki G. Hubungan Antara Suhu, Merokok dan Konsumsi Minuman Beralkohol dengan Terjadinya Disfungsi Ereksi Pada Sopir Angkutan Umum di Terminal Paal Dua Kota Manado Tahun 2014. JIKMU. 2015;5(2):192-201.

17. Calabro RS, Gervasi G, Naro A, Luca R De, Marullo M, Bramanti P. Erectile Dysfunction in Indiviuals with Neurologic Disability: A Hospital-based Cross-sectional Study. Innovations in Clinical Neuroscience 2016;13(1-2):10-14.

18. Hatzimouratidis K, Eardley I, Giuliano F, Moncada I, Salonia A, Laumann EO, et al. Erectile Dysfunction and Premature Ejaculation. Guidelines on Male Sexual Dysfunction. 2015;281(6):1-38.

19. Araujo AB, Travison TG, Ganz PA, Chiu GR, Kupelian V, Rosen RC, et al. Erectile Dysfunction and Mortality. J Sex Med. 2009;6(9):5.

20. Krismawati LDE, Andayani NLP, Wahyuni N. Hubungan Antara Aktivitas Fisik Dengan Indeks Massa Tubuh (IMT) Pada Remaja Usia 16-18 Tahun di SMA Negeri 2 Denpasar. Majalah Ilmiah Fisioterapi Indonesia. 2019;7(1): 2629

21. Burhan FZ, Sirajudin S, Indriasari R. Pola Konsumsi Terhadap Kejadian Obesitas Sentral Pada Pegawai Pemerintahan di Kantor Bupati Kabupaten Jeneponto. 2013;1-3.

22. Diaz-Arjonilla M, Schwarcz M, Swerdloff RS, Wang C. Obesity, Low Testosterone Levels and Erectile Dysfunction. International Journal of Impotence Research. 2009;21(2):89-98.

23. Aras D, Ahmad H, Ahmad A. The New Concept of Physical Therapist Test and Measurement. Edisi Pertama. Makasar: PhysioCare Publishing; 2016.

24. Feeley RJ, Traish AM. Obesity and Erectile Dysfunction: Is Androgen Deficiency the Common Link?. The Scientific World Journal. 2009;9:676-684.

25. Rakhmawati A. Hubungan Antara Indeks Massa Tubuh dengan Usia Awal Andropause. SKRIPSI. Universitas Sebelas Maret. 2009.

26. Wardana ING. Obesitas dan Kadar Testosteron yang Rendah. Bagian Anatomi FK UNUD. 2016;5-7. 